\title{
Analisis Kemampuan Berpikir Reflektif Siswa dalam Menyelesaikan Soal Matematika Materi Lingkaran
}

\author{
Siti Nurrohmah", ${ }^{1, *}$ Heni Pujiastuti ${ }^{2}$ \\ ${ }^{1,2}$ Universitas Sultan Ageng Tirtayasa \\ *sitinurmah13@gmail.com
}

\begin{tabular}{|l|l|l|l|}
\hline Received : 18-05-2020 & Revised: 05-07-2020 & Accepted: $19-09-2020$ & Published: 05-12-2020 \\
\hline
\end{tabular}

\begin{abstract}
ABSTRAK
Tujuan dari penelitian ini untuk mengetahui bagaimana kemampuan berpikir reflektif matematis siswa dalam menyelesaikan soal matematika dalam materi lingkaran. Metode yang dipakai peneliti adalah metode deskriptif kuantitatif. Sampel dalam penelitian ini yaitu kelas VIII-C SMP Negeri 1 Ciruas sebanyak 26 siswa. Teknik sampel yang digunakan adalah teknik purposive sampling. Metode penghimpunan data dengan memberikan soal materi lingkaran. Dari hasil studi memperlihatkan bahwa kemampuan berpikir reflektif matematis siswa dalam materi lingkaran masih belum optimal. Tampak dari hasil perolehan nilai siswa, diperoleh 3 siswa pada kelompok tinggi dengan persentase sebesar 11,53\%, 17 siswa pada kelompok sedang dengan persentase sebesar $65,4 \%$ dan 6 siswa pada kelompok rendah dengan persentase sebesar $23,7 \%$.
\end{abstract}

Kata Kunci : berpikir reflektif, penyelesaian masalah, lingkaran

\begin{abstract}
The purpose of this study is to find out how students' mathematical reflective thinking abilities in solving mathematical problems in circle material. The method used by researchers is a quantitative descriptive method. The sample in this study was class VIII-C of SMP Negeri 1 Ciruas with 26 students. The sample technique used is purposive sampling technique. The method of collecting data is by giving circle matter questions. From the results of the study show that the students' mathematical reflective thinking ability in the circle material is still not optimal. It can be seen from the results of the acquisition of student grades, obtained 3 students in the high group with a percentage of $11.53 \%, 17$ students in the moderate group with a percentage of $65.4 \%$ and 6 students in the low group with a percentage of $23.7 \%$.
\end{abstract}

Keywords: reflective thinking, problem solving, circles

\section{PENDAHULUAN}

Matematika ialah suatu pengetahuan yang menjadi landasan akan pengetahuan lain. Matematika merupakan ilmu yang diajarkan dari tingkat taman kanak-kanak hingga tingkat universitas (Fatwa, Septian, \& Inayah, 2019; Monariska, 2017). Mata pelajaran ini kerap dianggap sulit dan sedikit diminati oleh siswa karena matematika berkaitan dengan konsep-konsep yang abstrak (Herawati, Siroj, \& Basir, 2013; Maskur et al., 2020; Septian, Darhim, \& Prabawanto, 2020). Pada prinsipnya matematika melatih cara bernalar dan berpikir seseorang dalam menyimpulkan sebuah kesimpulan, mengelaborasikan 
kemampuan pemecahan masalah serta kemampuan komunikasi untuk menyampaikan keterangan dalam bentuk lisan, tulisan, diagram dan sebagainya (Depdiknas, 2006). Maka dari itu, kemampuan berpikir matematis menjadi standar dalam terlaksananya tujuan pembelajaran matematika (Hendriawan \& Septian, 2019).

Kemampuan berpikir matematis meliputi kemampuan berpikir kritis, kemampuan berpikir kreatif, kemampuan berpikir metakognitif dan kemampuan berpikir reflektif. Kemampuan tersebut tergolong dalam kemampuan berpikir tingkat tinggi (Budiman, 2019; Kusumaningrum \& Saefudin, 2012). Menurut Odiba \& Baba (2013) dalam proses pembelajaran, aspek penting yang harus terdapat pada siswa yaitu cara berpikir reflektif. Kemampuan berpikir reflektif merupakan cara berpikir siswa dalam melibatkan pengetahuan yang ditemukan dengan pengetahuan lamanya untuk menyelesaikan permasalahan (Rahmy, 2012).

Suharna (2012) juga mengutarakan bahwa berpikir reflektif diinterpretasikan sebagai proses memahami untuk dipelajari, menelaah, menilai, menstimulasi, memperoleh makna dan menggunakan rencana pembelajaran yang sesuai. McLeod, Barr, \& Welch, (2015) menyatakan bahwa ada tiga poin penting dalam berpikir reflektif yaitu : (1) curiosity merupakan keingintahuan untuk penjabaran kejadian-kejadian yang membutuhkan kebenaran secara eksplisit akan permasalahan yang dialami, (2) suggestion merupakan konsep yang dipertimbangkan berdasarkan pengalaman yang dimiliki dan mempunyai pilihan yang mendalam, dan (3) orderliness yaitu siswa harus mampu menyimpulkan ide-idenya untuk menyusun sebuah jawaban

Sabandar (2010) mengungkapkan bahwa siswa perlu terlibat dalam suatu pemecahan masalah untuk mengembangkan kemampuan berpikir reflektif siswa. Kemampuan tersebut memberikan peluang untuk belajar serta memikirkan pendekatan terbaik dalam mencapai target pembelajaran sehingga mendorong pemikiran siswa saat situasi pemecahan masalah. Pemecahan masalah dalam pembelajaran matematika adalah pemecahan atau penyelesaian pada latihan-latihan yang bersifat tidak rutin melalui beragam ide, prinsip dan keterampilan matematika yang sedang atau telah dipelajari (Aisyah, 2008; Septian \& Rizkiandi, 2017). Oleh karenanya, perlu bagi siswa untuk dilatih kemampuan pemecahan masalah dalam menyelesaikan persoalan matematika atau di bidang selain matematika.

Kemampuan pemecahan masalah secara jelas terdapat di kurikulum sebagai kompetensi dasar yang perlu dibangun dan diintegrasikan pada pelajaran (Fatimah et al., 2019; Muhammad, Septian, \& Sofa, 2018; Rahmawati, 2018). Begitu juga dengan 
kemampuan lain, kemampuan berpikir reflektif dibangun ketika siswa berada pada metode yang intensif tentang pemecahan masalah. Seperti langkah pemecahan masalah dari Polya, siswa mendapat keleluasaan dalam berpikir reflektif, yaitu melatih diri dari pengetahuan yang telah dilalui untuk menaikkan mutu belajarnya.

Kemampuan berpikir reflektif diperlukan oleh siswa karena bisa meningkatkan hasil belajar siswa yang maksimal. Akan tetapi pada kenyataannya kemampuan berpikir reflektif pun minim dilakukan oleh guru. Hal tersebut selaras dengan studi Nindiasari (2013) bahwasanya kemampuan berpikir reflektif siswa terbilang minim. Hal ini dipicu oleh beberapa penyebab diantaranya siswa belum dibiasakan untuk proses berpikir reflektif dan guru tidak melatih kemampuan tersebut. Padahal cara mengkontruksi sesuatu dalam proses pembelajaran haruslah seorang guru memulai refleksi dari pengetahuan atau pengalaman sendiri (Brooke, 2012).

Menurut Harel \& Sowder (2005) terkadang guru hanya mencermati perolehan akhir tanpa melihat langkah berpikir siswa dalam memperoleh hasil tersebut. Guru berulang kali menekankan dalam cara mendalami suatu materi, namun tidak mendorong siswa untuk berpikir cara efektif dalam mendalami materi tersebut. Akhirnya siswa menitikberatkan pada perolehan akhir tanpa memahami atau mendalami proses dari pemecahan masalah tersebut. Selain itu, dalam pemecahan masalah yang berkaitan dengan proses berpikir reflektif, membutuhkan waktu yang tidak sedikit untuk menemukan penyelesaian. Jika siswa sudah menemukan solusi, siswa sedikit merasa puas dan tidak ingin mengolah kembali apa yang didapatkannya (Sabandar, 2010).

Sementara itu, urgennya kemampuan berpikir reflektif sudah teruji oleh studi Suharna (2012) bahwa siswa yang berpikir secara reflektif memperoleh nilai yang lebih bagus dibandingkan dengan pembelajaran konvensional. Konteks persoalan yang diajukan menekan siswa untu berpendapat mengenai banyaknya proses dan hasil yang didapat, menggabungkan wawasan dan keterampilan, serta menata dan mengumpulkan kembali wawasan dan kecakapan untuk memudahkan cara menyelesaikan masalah (Masamah, Sujadi, \& Riyadi, 2015). Pada studi ini dipilih materi lingkaran dikarenakan lingkaran adalah salah satu prasyarat materi yang berkaitan dengan konsep trigonometri pada sekolah menengah atas dan berpautan dengan kehidupan sehari-hari. Hal yang sering dijumpai adalah menentukan luas dan keliling dari suatu benda yang berbentuk lingkaran. Dengan mempelajari materi lingkaran siswa mampu mengimplementasikan dalam aktivitas seharihari (Widiyawati, Septian, \& Inayah, 2020). 
Berdasarkan penjelasan tersebut, studi ini bertujuan untuk mengetahui bagaimana kemampuan berpikir reflektif matematis siswa SMP Negeri 1 Ciruas dalam menyelesaikan soal matematika materi lingkaran.

\section{METODE PENELITIAN}

Studi penelitian ini memakai metode penelitian deskriptif kuantitatif. Studi ini dilakukan di SMP Negeri 1 Ciruas Semester Genap Tahun Akademik 2019/2020. Populasi pada penelitian ini adalah siswa kelas VIII. Sampel dalam penelitian ini yaitu kelas VIII-C sebanyak 26 siswa. Teknik sampel yang digunakan adalah teknik purposive sampling, yaitu teknik pengambilan data berdasarkan pertimbangan tertentu (Sugiyono, 2010). Pada studi ini, metode penghimpunan data yang digunakan adalah dengan memberikan soal materi lingkaran. Soal tersebut digunakan untuk mendapatkan gambaran kemampuan reflektif matematis siswa. Kemudian data diolah dan dianalisis berdasarkan hasil perolehan nilai siswa. Dari hasil peroleh tersebut lalu dikategorikan dalam kelompok rendah, sedang dan tinggi (Sudijono, 2008). Kriteria pengategorian siswa berdasarkan nilai rerata dan simpangan baku.

Adapun indeks kemampuan berpikir reflektif matematis yang diadaptasi dari Surbeck, Han dan Moyer dalam (Ariestyan, Sunardi, \& Kurniati, 2016) sebagai berikut:

Tabel 1. Indeks Kemampuan Berpikir Reflektif Matematis

\begin{tabular}{ll}
\hline Tingkatan & \multicolumn{1}{c}{ Indeks } \\
\hline Reacting & a. Menyatakan sesuai yang ditanyakan \\
& b. Menyatakan sesuai yang diketahui \\
& c. Menyatakan kaitannya antara yang ditanya dengan yang \\
& diketahui \\
& d. Dapat menguraikan sesuai yang diketahui sudah cukup untuk \\
& menjawab sesuai yang ditanyakan \\
Comparing & a. Menguraikan jawaban akan persoalan yang telah diperoleh \\
& b. Menautkan masalah yang ditanyakan dengan masalah yang \\
& antemplating \\
& a. Menetapkan maksud dari persoalan \\
& b. Menemukan kekeliruan pada jawaban \\
& c. Mengubah dan menguraikan bila terdapat kekeliruan pada \\
& d. Memaban
\end{tabular}

\section{HASIL DAN PEMBAHASAN}

Hasil studi ini diperoleh dari 26 siswa kelas VIII-C yang sudah mempelajari materi lingkaran. Kemudian dapat terlihat cara berpikir reflektif siswa dalam menyelesaikan soal 
materi lingkaran. Kemampuan berpikir reflektif matematis siswa terdiri dari tiga tingkatan yaitu reacting, comparing dan contemplating yang sesuai dengan pandangan Surbeck, Han dan Moyer dalam (Ariestyan et al., 2016).

Selanjutnya dipilih tiga subjek dengan inisial S25, S24 dan S8 berdasarkan kelompok rendah, sedang dan tinggi. Untuk memperoleh kelompok rendah, sedang dan tinggi dalam berpikir reflektif matematis, peneliti memakai nilai rerata dan simpangan baku sebagai tumpuan dalam kategorisasi atau pengelompokkan. Kelompok rendah diperoleh dari selisih nilai di bawah rerata dengan hasil simpangan baku. Pada kelompok sedang diperoleh dari hasil diantara selisih nilai di bawah rerata dengan hasil simpangan dan rerata dengan ditotalkan hasil simpangan baku. Sementara itu, untuk kelompok tinggi diperoleh dari nilai di atas rerata dan ditotalkan dengan hasil simpangan baku (Arikunto, 2010). Adapun hasilnya sebagai berikut.

Tabel 2. Tingkat Kemampuan Berpikir Reflektif Siswa

\begin{tabular}{cclcc}
\hline Kelompok & Kriteria Nilai & \multicolumn{1}{c}{ Inisial } & $\begin{array}{c}\text { Jumlah } \\
\text { Siswa }\end{array}$ & $\begin{array}{c}\text { Persentase / } \\
\text { Persentase } \\
(\%)\end{array}$ \\
\hline Rendah & $<33,22$ & S2, S11, S16, S21, & 6 & 23,07 \\
Sedang & $33,22<$ Nilai $<66,54$ & $\begin{array}{l}\text { S25, S26 } \\
\text { S1, S3, S4, S5, S6, }\end{array}$ & 17 & 65,4 \\
& & S7, S10, S12, S13, & & \\
& & S14, S15, S17, S18, & & \\
Tinggi & $>66,54$ & S20, S22, S23, S24 & 3 & 11,53 \\
\hline
\end{tabular}

Pada tabel 2. Menunjukkan tingkatan kelompok kemampuan berpikir reflektif matematis siswa. Terdapat 6 siswa memperoleh nilai di bawah 33,22 termasuk kelompok rendah dengan persentase sebesar 23,07\%. Untuk siswa dengan kelompok sedang memperoleh hasil terbanyak dan persentase terbesar yaitu sejumlah 17 siswa dan 65,4\%. Selain itu terdapat 3 siswa mencapai nilai di atas 66,54 termasuk kelompok tingkat tinggi dengan persentase sebesar $11,53 \%$. Hal ini memperlihatkan bahwa rata-rata siswa kelas VIII-C sedikit menguasai masalah yang berkaitan dengan lingkaran, khususnya dalam berpikir reflektif matematis. Selain itu, terlihat dari beberapa penyelesaian siswa dimana dalam proses pengerjaannya benar, tetapi salah pada hasil akhir. Meskipun demikian, siswa masih mendapatkan nilai yang merujuk pada indeks kemampuan berpikir reflektif matematis. Perbandingan persentase atau persentase kemampuan berpikir reflektif matematis siswa dalam menyelesaikan soal lingkaran terlihat pada Gambar 1. 


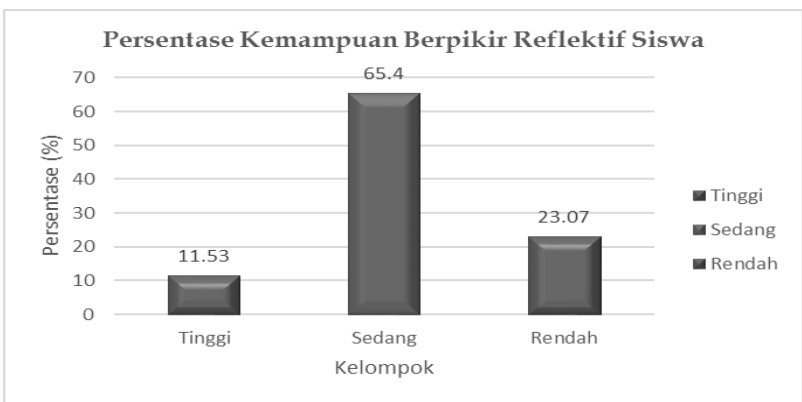

Gambar 1. Persentase Kemampuan Berpikir Reflektif Matematis Siswa dalam Menyelesaikan Soal Lingkaran

Adapun soal yang diberikan sebagai berikut: Sebuah lapangan berbentuk lingkaran memiliki keliling sebesar $88 \mathrm{~m}$. Tentukan luas dari lapangan tersebut. Berikut adalah hasil dari beberapa jawaban siswa dari kelompok rendah, sedang dan tinggi dalam menyelesaikan soal materi lingkaran

$$
L=\pi \times r \times r
$$

Gambar 2. Jawaban dari subjek S25

Berdasarkan Gambar 2, hasil penyelesaian dari subjek S25 yang termasuk kelompok rendah, subjek tidak menyatakan sesuai yang diketahui dan yang ditanyakan dari soal. Subjek juga tidak menyatakan kaitannya antara yang ditanya dengan yang diketahui dan tidak dapat menguraikan sesuai yang diketahui belum cukup untuk menjawab sesuai yang ditanyakan, maka semua indeks pada tingkatan reacting tidak memenuhi. Selanjutnya pada tingkatan comparing, subjek tidak menjabarkan hasil permasalahan yang didapatkan. Akan tetapi subjek hanya menuliskan rumus dari luas lingkaran. Selain itu, subjek kurang mampu mendefinisikan maksud dari permasalahan tersebut yaitu mencari luas lingkaran dengan menggunakan rumus keliling lingkaran yang sudah diketahui nilainya dan mendapatkan diamater lingkaran. Subjek tidak memberikan kesimpulan dari permasalahan tersebut, maka indeks dari tingkatan contemplating subjek sangat kurang. Berdasarkan analisis tersebut dapat disimpulkan bahwa subjek S25 dalam memecahkan masalah tidak memenuhi tingkatan reacting, comparing dan contemplating. Dengan demikian subjek S25 sangat kurang dalam berpikir reflektif matematis. 


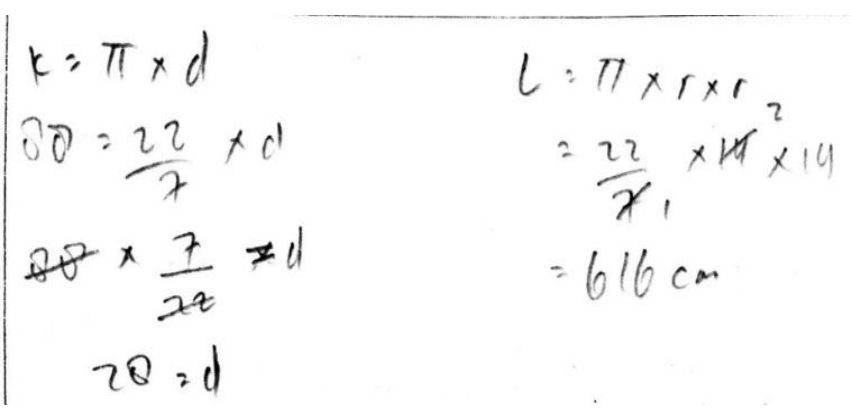

Gambar 3. Jawaban dari subjek S24

Berdasarkan Gambar 3, hasil penyelesaian subjek S24 yang termasuk tingkat kelompok sedang, subjek mampu menyatakan sesuai yang diketahui dan yang ditanyakan dari soal. Subjek menyimbolkan huruf "K" sebagai keliling lingkaran dan huruf "L" sebagai luas lingkaran. Hal ini sesuai dengan yang diungkapkan oleh Skemp (dalam Suharna, 2012) bahwa kemampuan berpikir reflektif dapat dideskripsikan sebagai informasi yang dipakai untuk menelaah, dapat menguraikan apa yang telah dilakukan, serta mampu untuk merealisasikan konsep dengan simbol atau gambar . Subjek tidak menyatakan sesuai yang diketahui dan yang ditanyakan dari soal. Namun subjek dapat menyatakan kaitannya antara yang ditanya dengan yang diketahui dan menguraikan sesuai yang diketahui sudah cukup untuk menjawab sesuai yang ditanyakan. Sehingga ada beberapa indeks yang tidak memenuhi tingkatan reacting. Selanjutnya pada tingkatan comparing, subjek mampu menguraikan hasil permasalahan yang didapatkan. Selain itu subjek mampu mendefinisikan maksud dari permasalahan tersebut yaitu mencari luas lingkaran dengan menggunakan rumus keliling yang sudah diketahui nilainya dan mendapatkan diameter lingkaran. Namun subjek tidak menuliskan satuan dari diameter lingkaran, salah menuliskan satuan dari luas lingkaran serta tidak memberikan kesimpulan dari permasalahan tersebut. Maka indeks dari tingkatan contemplating subjek masih kurang. Berdasarkan analisis tersebut dapat disimpulkan bahwa subjek S24 dalam memecahkan masalah memenuhi tingkatan comparing. Sementara itu, pada tingkatan reacting dan contemplating subjek masih kurang karena terdapat beberapa indeks yang belum dikuasai oleh subjek S24.

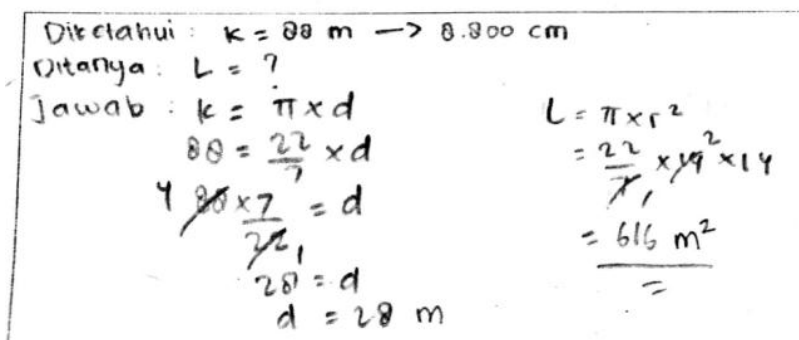

Gambar 4. Jawaban dari subek S8 
Berdasarkan Gambar 4, hasil penyelesaian dari subjek S8 yang termasuk kelompok tinggi, subjek mampu menyatakan sesuai yang diketahui dan yang ditanyakan dari soal. Subjek menyimbolkan huruf "K" sebagai keliling lingkaran dan huruf "L" sebagai luas lingkaran. Subjek juga mampu menyatakan kaitannya antara yang ditanya dengan yang diketahui dan mampu menyatakan sesuai yang diketahui sudah cukup untuk menjawab sesuai yang ditanyakan. Sehingga subjek mencakup semua indeks dari tingkatan reacting. Selanjutnya pada tingkatan comparing, subjek menguraikan hasil permasalahan yang didapatkan. Hal ini selaras dengan pernyataan Rahmy (2012) bahwa berpikir reflektif adalah cara berpikir siswa melibatkan pengetahuan yang ditemukan dengan pengetahuan lamanya untuk menyelesaikan permasalahan. Selain itu, subjek dapat mendefinisikan maksud dari permasalahan tersebut yaitu mencari luas lingkaran dengan menggunakan rumus keliling lingkaran yang sudah diketahui nilainya dan mendapatkan diameter lingkaran. Subjek juga menuliskan satuan dari diameter dan luas lingkaran tersebut dengan benar. Namun subjek tidak memberikan kesimpulan dari permasalahan tersebut, maka indeks dari tingkatan contemplating subjek adalah cukup menguasai. Berdasarkan analisis tersebut dapat disimpulkan bahwa subjek S8 dalam memecahkan masalah matematika memenuhi tingkatan reacting dan comparing. Namun pada tingkatan contemplating subjek dikatakan cukup memenuhi karena terdapat satu indeks yang tidak memenuhi yaitu tidak membuat kesimpulan dengan benar.

Dari pembahasan penelitian mengenai kemampuan berpikir reflektif siswa dalam menyelesaikan soal matematika materi lingkaran, dapat disimpulkan bahwa kemampuan berpikir reflektif siswa bermacam-macam. Terdapat beberapa siswa dengan kemampuan berpikir reflektif tinggi, yaitu menguasai tingkatan reacting, comparing dan contemplating yang cukup. Selain itu, sebagian siswa hanya mampu berpikir reflektif pada tingkatan reacting dan comparing dikatakan mempunyai kemampuan berpikir reflektif sedang. Serta terdapat beberapa siswa yang hanya mampu berpikir reflektif pada tingkatan pertama saja, yaitu reacting dikatakan mempunyai kemampuan berpikir reflektif rendah.

\section{KESIMPULAN}

Berdasarkan hasil studi dan pembahasan yang sudah dilaksanakan peneliti mengenai kemampuan berpikir reflektif siswa kelas VIII-C SMP Negeri 1 Ciruas dalam menyelesaikan soal materi lingkaran, maka dapat disimpulkan bahwa kemampuan berpikir reflektif siswa belum optimal. Selain itu siswa rata-rata menguasai tingkatan comparing dimana siswa mampu menguraikan hasil jawaban pada permasalahan yang pernah 
diperoleh. Namun untuk tingkatan reacting dan contemplating masih belum optimal karena banyak siswa tidak menyebutkan apa yang ditanyakan dan diketahui serta tidak membuat kesimpulan dengan benar.

\section{REFERENSI}

Aisyah, N. (2008). Pendekatan Pemecahan Masalah Matematika. Pembelajaran Matematika Sekolah Dasar, 1-34.

Ariestyan, Y., Sunardi, S., \& Kurniati, D. (2016). Proses Berpikir Refllektif Siswa dalam Menyelesaikan Soal Matematika Materi Sistem Persamaan Linear Dua Variabel. KadikmA: Jurnal Matematika Dan Pendidikan Matematika, 7(1), 94-104.

Arikunto, S. (2010). Prosedur Penelitian Suatu Pendekatan dan Praktik. Jakarta: PT. Rineka Cipta.

Brooke, M. (2012). Enhancing Pre-Service Teacher Training: The Construction and Application of a Model for Developing Teacher Reflective Practice Online. Open Journal of Modern Linguistics, 2(4). https://doi.org/10.4236/ojml.2012.24023

Budiman, H. (2019). Mengukur Kemampuan Berpikir Reflektif Matematis Mahasswa pada Materi Diferensiasi dan Integrasi Numerik. PRISMA, 8(1), 58-67. https://doi.org/10.35194/jp.v8i1.380

Depdiknas. (2006). Peraturan Menteri Pendidikan Nasional Republik Indonesia No 22 Tahun 2006 tentang Standar Isi untuk Satuan Pendidikan Dasar dan Menengah. In Departemen Pendidikan Nasional.

Fatimah, R. N., Kariadinata, R., Susilawati, W., Jihad, A., Nur, I., Fauziah, ... Sugilar, H. (2019). Teknik Probing-Promting Scaffolding pada Pemecahan Masalah Matematis. Prisma, 8(2), 146-159.

Fatwa, V. C., Septian, A., \& Inayah, S. (2019). Kemampuan Literasi Matematis Siswa melalui Model Pembelajaran Problem Based Instruction. Mosharafa: Jurnal Pendidikan Matematika, 8(3), 389-398.

Harel, G., \& Sowder, L. (2005). Advanced Mathematical-Thinking at Any Age: Its Nature and Its Development. Mathematical Thinking and Learning, 7(1), 27-50. https://doi.org/10.1207/s15327833mt10701_3

Hendriawan, M. A., \& Septian, A. (2019). Pengembangan JiMath Sebagai Multimedia Pembelajaran Matematika Berbasis Android Untuk Siswa Sekolah Menengah Atas. IndoMath: Indonesia Mathematics Education, 2(1), 45. https://doi.org/10.30738/indomath.v2i1.2785

Herawati, O. D. P., Siroj, R., \& Basir, D. (2013). Pengaruh Pembelajaran Problem Posing Terhadap Kemampuan Pemahaman Konsep Matematika Siswa Kelas Xi Ipa Sma Negeri 6 Palembang. Jurnal Pendidikan Matematika, 4(1), 71-80.

Kusumaningrum, M., \& Saefudin, A. A. (2012). Mengoptimalkan Kemampuan Berpikir Matematika melalui Pemecahan Masalah Matematika. Prosiding Kontribusi Pendidikan Matematika Dan Matematika Dalam Membangun Karakter Guru Dan Siswa, (November), 978-979.

Masamah, U., Sujadi, I., \& Riyadi, R. (2015). Proses Berpikir Reflektif Siswa Kelas X Man Ngawi Dalam Pemecahan Masalah Berdasarkan Langkah Krulik Dan Rudnick Ditinjau Dari Kemampuan Awal Matematika. Journal of Mathematics and Mathematics Education, 5(1), 38-50. https://doi.org/10.20961/jmme.v5i1.10008

Maskur, R., Sumarno, Rahmawati, Y., Pradana, K., Syazali, M., Septian, A., \& Palupi, E. K. (2020). The effectiveness of problem based learning and aptitude treatment 
interaction in improving mathematical creative thinking skills on curriculum 2013. European Journal of Educational Research, 9(1), 375-383. https://doi.org/10.12973/eu-jer.9.1.375

McLeod, G. A., Barr, J., \& Welch, A. (2015). Best Practice for Teaching and Learning Strategies to Facilitate Student Reflection in Pre-Registration Health Professional Education: An Integrative Review. Creative Education, 6(4), 440-454. https://doi.org/10.4236/ce.2015.64044

Monariska, E. (2017). Penerapan Metode Mind Mapping untuk Meningkatkan Kemampuan Pemahaman Konsep Matematis Mahasiswa pada Mata Kuliah Kalkulus I. PRISMA, 6(1), 17-31. https://doi.org/10.35194/jp.v6i1.25

Muhammad, G. M., Septian, A., \& Sofa, M. I. (2018). Penggunaan Model Pembelajaran Creative Problem Solving untuk Meningkatkan Kemampuan Pemecahan Masalah Matematis Siswa. Mosharafa: Jurnal Pendidikan Matematika, 7(3), 315-326. https://doi.org/10.31980/mosharafa.v7i3.140

Nindiasari, H. (2013). Meningkatkan Kemampuan dan Disposisi Berpikir Reflektif Matematis Serta Kemandirian Belajar Siswa Melalui Pembelajaran Dengan Pendekatan Metakognitif. Disertasi.

Odiba, I. A., \& Baba, P. A. (2013). Using Reflective Thinking Skills for Education Quality Improvement in Nigeria. 4(16), 196-202.

Rahmawati, N. I. (2018). Pemanfaatan ICT dalam Meningkatkan Kemampuan Literasi Matematika. PRISMA, 1, 381-387.

Rahmy, Z. (2012). Pengaruh Pembelajaran dengan Pendekatan Proses Berpikir Reflektif terhadap Peningkatan Kemampuan Koneksi dan Berpikir Kritis Matematis Siswa. Universitas Pendidikan Indonesia.

Sabandar, J. (2010). Berpikir Reflektif dalam Pembelajaran Matematika. 1-17.

Septian, A., Darhim, \& Prabawanto, S. (2020). Mathematical representation ability through geogebra-assisted project- based learning models. Journal of Physics : Conference Series, 1657(1), 12019. https://doi.org/10.1088/1742-6596/1657/1/012019

Septian, A., \& Rizkiandi, R. (2017). Penerapan Model Problem Based Learning (PBL) terhadap Peningkatan Kemampuan Berpikir Kreatif Matematis Siswa. PRISMA, 6(1). https://doi.org/10.35194/jp.v6i1.22

Sudijono, A. (2008). Pengantar Evaluasi Pendidikan. Jakarta: Raja Grafindo Persada.

Sugiyono. (2010). Metode Penelitian Bisnis. Bandung: Alfabeta.

Suharna, H. (2012). Berpikir Reflektif (Reflective Thinking) Siswa SD Berkemampuan Matematika Tinggi Dalam Pemahaman Masalah Pecahan. Prosiding, (November), 377-386.

Widiyawati, W., Septian, A., \& Inayah, S. (2020). Analisis Kemampuan Koneksi Matematis Siswa SMK pada Materi Trigonometri. Jurnal Analisa, 6(1), 28-39. https://doi.org/10.15575/ja.v6i1.8566 